\title{
Analysing Style and Autobiographical Element in Alice Munro's “Dear Life”
}

\author{
Moayad Ahmad Alshara, MA \\ Foreign Languages Department, Faculty of Arts, Taif University, KSA \\ M.Phil. English Literature Scholar, IELL, \\ University of Sindh, Jamshoro, Pakistan
}

Abdul Hameed Panhwar, Assistant Professor

Institute of English Language and Literature, University of Sindh, Jamshoro, Pakistan

Marwa Adel Hasan, Lecturer of Linguistics,

Faculty of Arts, Mansoura University, Egypt

doi: 10.19044/esj.2017.v13n11p34 URL:http://dx.doi.org/10.19044/esj.2017.v13n11p34

\begin{abstract}
The paper aims to stylistically analyze the autobiographical elements in Alice Munro’s Story “Dear Life.” It is discovered that from the starting to the end of the story, it is full of the events which are very closely linked to Munro's own life. Although the events have close resemblance to Munro's life, these are factiously and artistically depicted so that they serve the purpose of literature and the stylistic aspects of the story. The researchers in the paper analyze and discuss the stylistic characteristics of the author with the help of the textual evidence from the story and to further support these, they cite the literature on the similar aspects. Finally, it is found that Munro's fantastic style and the blend of the autobiographical facts and fiction make her story 'Dear Life' very interesting and worth reading.
\end{abstract}

Keywords: Alice Munro, autobiographical, life, fiction, style

\section{Introduction}

Alice Munro is a Canadian regionalist writer. She was born in Ontario in1931. Munro has received many awards and prizes for her global contribution to fiction. She is described as the "master of the contemporary short story" (nobelprize.org). A winner of the Nobel Prize for Literature in 2013, Munro is well-known for her Too Much Happiness, Lives of Girls and Women, and Dear Life. Her stories appear in the New Yorker, Atlantic Monthly, Paris Review and other publications. Her stories have been translated into many languages. 
The aim of this study is to shed light on Munro's stylistic features through her short story "Dear Life". Munro's fiction writing style is realistic and free of mawkishness. By a close reading of the collection of her short stories, one may notice how her writing style frequently displays autobiographical, historical, gothic, and regional features (Murphy, 2009). The setting of most of her short stories starts from her birth-place, Ontario, to include, British Columbia, Ireland Scotland, central Europe, and even Australia. This is clear, for example, in her 1988 work "Meneseteung," whose title refers to the Native American name of the river commonly known as the Maitland or Peregrine. This story offers a detailed, straightforward view of life of the Ontario region. The study also aims at showing one of the prominent features of Munro's style, namely the autobiographical element that permeates her "Dear Life."

\section{Literature Review}

The opening sentence of her short story "Dear Life (2012)" shows how Munro uses sentence structure in such a way as to manifest the regional features of her short story under study: "I lived when I was young at the end of a long road, or a road that seemed long to me" (Munro, 2012, p. 585). Obviously, the repetition of the word 'road' serves to emphasize the author's intimacy with the place of her childhood.

In her introductory paragraph, the reader is introduced to the unique individuality of the narrator - a little girl at the beginning of the storywhen she describes:

...two bridges over the Maitland River: one narrow iron bridge, where cars sometimes go into trouble over which one should pull off and wait for the other, and a wooden walkway which occasionally had a plank missing, so that you could look right down into the bright, hurrying water. I liked that, but somebody always came and replaced the plank eventually ${ }^{39}$ (Munro, 2012, p.585).

The introduction displays not only a unique sense of place-marking in Munro's stories of small-town life, but also her psychological insights into the lives of her characters, particularly the little narrator.

Hoy (1980, html) states that Munro's writing style "places fantastic next to the ordinary, with each undercutting the other in ways that simply and effortlessly evoke life". Hoy continues to say that Munro's prosaic writing style reveals the ambiguities of life: "ironic and serious at the same time," "mottoes of godliness and honor and flaming bigotry," "special, useless knowledge," "tones of shrill and happy outrage," and "the bad taste, the heartlessness, the joy of it."

\footnotetext{
${ }^{39}$ This and subsequent quotations are from Dear Life(2012) by Alice Munro
} 
Regarding Alice Munro's prose writing style, MacKendrick and Thacker (1998, p. 128) state that:

Munro's writing creates... an empathetic union among readers, critics most apparent among them. We are drawn to her writing by its verisimilitude - not of mimesis, so-called and... 'realism' - but rather the feeling of being itself... of just being a human being.

It is obvious that Munro's unique, genuine, and credible writing style calls the reader's attention to the unity between the readers and critics. Murphy (2009, p. 41) further adds that "to an extraordinary extent, the raw material of Munro's work comes from her own life, a fact she readily admits."

In matters of style, Munro's short stories are often compared with the great short-story writers, such as William Faulkner, Anton Chekhov, Kate Chopin, to name only a few. Therefore, one would easily notice that in many of her stories, as in Chekhov's, the prime focus is on the characters whereas plot is of secondary importance and that "little happens" in most of her works. Holcombe (2005, p. 26) notes that in Munro's fiction: "All is based on the epiphanic moment, the sudden enlightenment, and the concise, subtle, revelatory detail." In his critical appreciation of Munro’s writing style, Boyd (2014, pp. pp. 12-14) notes that:

[s] he [Munro] employs a variety of devices to create the sense of a life extended through time.... the most frequently employed of these devices is her rejection of linear chronology in favor of time-shifts, often jumping backwards to fill in the past or leaping forward, shocking us with the changes wrought by time. These shifts are clearly marked by Munro's segmentation of her text, triple-spacing between sections running from one to six or seven pages in length. Reading one of her stories for the first time, I am constantly aware of how impossible it is to predict where in the central character's life she is taking us next. Only when we reach the end of the story does the ordering of the different parts seem essential to the effects created by the narrative as a whole.

Thus, Munro's 'rejection of linear chronology' is clearly shown in the time-shifting she uses in her short story "Dear Life" and many other works. Bloom (2009, p. 42) argues that "the chronological and geographical settings of Munro's stories roughly reiterate this life pattern of departure and return” In "Dear Life”, Munro - as one might say — moves freely between the unities of time, using the present then the past and at some other times the future. These 'time-shifts' are best shown by the little-girl narrator who says: "It was a beautiful day in the fall. I had been set out to sleep in my baby carriage on the little patch of new lawn” (Munro, 2012, p. 609). These two sentences obviously demonstrate how Munro cleverly deviates from the 
main course of the story into something the narrator recalls from her past. Thus, Munro moves between the three time zones - the present, the past, and the future - in narrating her story. Again, she uses another time zone when she says: "After I was married and had moved to Vancouver, I still got the weekly paper that was published in the town where I grew up" (Munro, 2012, p. 619). One can also infer from these sentences that Munro presents some of her real life experiences in this short story.

\section{Critical Analysis of the story with special focus on Munro's style and autobiographical touch}

Concerning the autobiographical elements in Munro's work, her collection of short stories Dear Life has dealt with personal experiences. As Bloom (2009, p. 42) notes that “[h]er work is so closely related to her life." It is; therefore, evident that on many occasions, Munro has acknowledged her leaning to transform some of her actual experiences into fiction. She further declares that some of the stories in Dear life have much to do with her autobiography. One of these stories is "Dear life." Similarly, In his The Sense of an Ending: "Dear Life," Stories by Alice Munro, an article published in the New York Times, Mcgrath (2012, html) notes that "Munro has never been an autobiographical writer in the strictest sense - not the way Updike was, for example - and yet certain themes and patterns in the stories more or less parallel the trajectory of her own life".

In particular, Munro attempts to transform events in the world into meaningful fiction. Her "Dear Life" bears this assertion out. The story is about life on a farm, the protagonist (Alice Munro)'s growing up in Wingham, and her relationship with her parents, particularly, after her mother has fallen ill with a serious disease. The story reveals a sort of authorial confession and discloses long-hidden feelings. Of this story and some others in the collection, the author suggests that they are greatly inspired by her life experiences.

In Munro's “Dear Life,” setting and people are very important as they constitute a great deal of her personal experiences. More particularly, much of the action of the story is set in the area in which the author has grown up. For example, the narrator (Alice) talks about real places including the Maitland River that lies at the town in which she lives:

I lived when I was young at the end of a long road, or a road that seemed long to me. Back behind me, as I walked home from primary school, and then from high school, was the real town with its activity and its sidewalks and its streetlights for after dark. Marking the end of town were two bridges over the Maitland River: one narrow iron bridge, where cars sometimes got into trouble over which one should pull off and wait for the other, and a wooden walkway which 
occasionally had a plank missing, so that you could look right down into the bright, hurrying water (Munro, 2012, p. 585).

The author's minute description of the region in which she has been raised is highly autobiographical. Moreover, it reflects the author's familiarity with the place where she is brought up and the great affection which she bears for it. The minute details - 'sidewalks,' 'streetlights,' 'two bridges,' 'wooden walk way,' and 'plank' - suggest the writer's attachment to the area of her childhood and demonstrate how personal her memories are. In addition, her reference to the objects, hardly observed by other people, testifies to the autobiographical element underlying the story. The opening paragraph shows that most of Munro's stories embody the locale coloring, i.e. she sets her stories in her birthplace of Ontario. This regional concern is considered one of the dominant characteristics of her story writing. Many critics argue that her regional setting is like that of the South American, such as William Faulkner and Flannery O’Connor (http://alicemunrofestival.ca/?page_id=2). Furthermore, critics add that Munro's characters are in a constant confrontation with stringent conventions, but they respond in a less intense than those of Faulkner and O'Connor. For example, Munro's male characters represent the spirit of the ordinary man, whereas her female characters display intricate personalities. It is, therefore, evident that most of Munro's fiction represents an autobiographical setting which paves the way to what is known as the Southern Ontario Gothic.

What further illustrates the autobiographical underpinnings of "Dear Life" is the author's description of the view of the lawns that lie outside her home. She specifically refers to where the elm trees have grown:

I had the help of the elm trees, which hung over the pasture, and the shining river, and the surprise of a spring that came out of the bank above the pasture, providing water for the doomed horses and the cow and also for me, out of a tin mug I brought there (Munro, 2012, pp. 597-98).

Elsewhere, the narrator observes that "they were elms, which had all died of Dutch elm disease by now" (p. 621). If this indicates anything, it shows how most of Munro's personal experiences are materialized in her short story.

In addition to the actual places and elm trees mentioned by the author, we are told that her parents have bought a farm in 1927 and that a number of families have lived there before, but Munro has regarded it as her own and hardly accepted anyone else growing up in the same place, enjoying the same landscapes and sharing the same emotions: "That was our bank. My bank . . . Our house” (pp. 621- 623). This emphasizes over and over again 
the close resemblance between the author's real experiences and those narrated by the protagonist.

People also play an important role in Munro’s “Dear Life,” since they shed much light on the author's actual experiences and their manifestation in her short story. Munro's relationship with her parents in particular is greatly reflected in the protagonist. The following lines demonstrate the similarity between the business of the author's business and that of the narrator of "Dear Life":

The truth was that my father had got into the fur business just a little too late. The success he'd hoped for would have been more likely back in the mid-twenties, when furs were newly popular and people had money (Munro, 2012, p. 601).

The author's father and that of the narrator also share the same declining experience of their businesses:

After the optimism of that season of redecoration, however, our business dried up again, and this time it never came back. My father pelted all the foxes, then the mink, and got what shockingly little money he could for them, then he worked by day pulling down the sheds where that enterprise had been born and had died, before heading off to take the five-o'clock watch in the foundry. He would not come home until around midnight (Munro, p. 603).

Obviously, the minute details given by the narrator about the failure of her father's business testify to the autobiographical element inherent in "Dear Life” and assert Munro’s propensity to convert one of her father's real experiences into fiction.

The narrator's interaction with her father has also an autobiographical reference. On many occasions, the narrator used to act offensively towards her own mother, the result of which is that she is punished by her father. The incident involving the narrator 'talking back,' thus hurting her mother's feelings echoes Munro's casual ill-behavior towards her mother:

Later on, I had to stay in the house to help my mother, and I was full of resentment and quarrelsome remarks. "Talking back" it was called. I hurt her feelings, she said, and the outcome was that she would go to the barn to tell on me, to my father. Then he'd have to interrupt his work to give me a beating with his belt (Munro, p. 598).

Perhaps, Munro's close attachment to her father has driven her to document some of his experiences in the short story under discussion.

Munro’s mother has made several appearances in her short stories, which demonstrates the author's difficult relationship with her mother and exhibits the autobiographical component of "Dear Life." For example, Munro's mother used to tell on her whenever she behaves improperly. As mentioned above, the child is punished by her father and she "lie[s] weeping 
in bed and make plans to run away” (p. 599). This incident is one of the autobiographical features of the short story under study.

The protagonist's reference to her mother's incurable illness presents another autobiographical component. The minute details about that illness and its symptoms, as reported by the narrator, echo the author's will to record how much her mother suffered from that disease and attempted to put up with it:

Something had come upon us that was even more unexpected and would become more devastating than the loss of income, .... It was the early onset of Parkinson's disease, which showed up when my mother was in her forties. At first, it was not too bad. Her eyes only rarely turned up into her head in a wandering way, and the soft down from an oversupply of saliva was just visible around her lips. She could get dressed in the mornings with some help, and she was able to do occasional chores around the house. She held on to some strength in herself for a surprisingly long time (Munro, p. 604).

Clearly, Munro is careful about pointing out the maternal-filial bond that ties her with her mother and grows strong following her illness, which explains the reason she wants to record it in "Dear Life." The author cannot get over the fact of her mother's fatal disease which has kept haunting her throughout her life.

Another incident in "Dear Life" which displays one more autobiographical component of the story involves the narrator's coming across an old, but never used golf bag. The narrator thinks that the golf bag might be associated with her mother's desire for a more sophisticated life. Reflecting on her mother's expectation of a classy life, the narrator says:

She must have thought that she and my father were going to transform themselves into a different sort of people, people who enjoyed a degree of leisure. Golf. Dinner parties (Munro, p. 595).

However, her mother's weakness is her inability to see that there are class barriers which preclude her dreams of a life different from the farm life which she has got used to:

Perhaps she had convinced herself that certain boundaries were not there. She had managed to get herself off a farm on the bare Canadian Shield-a farm much more hopeless than the one my father came from - and she had become a schoolteacher, who spoke in such a way that their own relatives were not easy around her. She might have got the idea that after such striving she would be welcomed anywhere (Munro, p. 595).

Elsewhere, the narrator points out that "Her (mother's) fault was that she did not look like what she was. She did not look as if she had been brought up on a farm, or as if she intended to remain on one” ( Munro 2012, 
pp. 611-12). Clearly, the faults of the narrator's mother bear similarity with those of Munro's mother, which emphasizes the autobiographical characteristic in the story.

Munro used to listen to and interact with her mother about the latter's younger days. This also finds expression in "Dear Life," particularly when the narrator recounts and responds to her mother's engaging stories about a house belonging to a war veteran called Waity Streets and about a mysterious woman called Mrs. Netterfield, who happens to live in the house long before she does. Reflecting on this, the narrator reports:

Sometimes my mother and I talked, mostly about her younger days. I seldom objected now to her way of looking at things. Several times, she told me a story that had to do with the house that now belonged to the war veteran named Waitey Streets. ... The story was not about him but about someone who had lived in that house long before he did, a crazy old woman named Mrs. Netterfield (Munro, 2012, p. 607-08).

A further autobiographical component of "Dear life" figures most clearly in the narrator's account of her marriage and subsequent inability to see her mother during her last illness or attend her funeral rites. The narrator, or rather the author, expresses her regret about her failure to see her mother for the last time:

I did not go home for my mother's last illness or for her funeral. I had two small children and nobody in Vancouver to leave them with. We could barely have afforded the trip, and my husband had a contempt for formal behavior, but why blame it on him? I felt the same. We say of some things that they can't be forgiven, or that we will never forgive ourselves. But we do-we do it all the time. (Munro, 2012, p. 624-25)

\section{Conclusion}

In conclusion, the setting and characters in "Dear Life" have autobiographical foundations. They reflect the author's actual experiences that include her relationships with the place she has lived in and the people, her parents in particular, she has lived and interacted with. Munro's mother in particular has turned out to be the model for most of her fictional female characters both in her "Dear Life" and many other short stories.

\section{References:}

1. Bloom, H. (2009). Alice Munro: Bloom's Modern Critical Views. USA: Infobase Publishing. P. 42.

2. Boyd, M. (2014). Alice Munro: An Appreciation. Bridgewater Review, 33(1), 12-14. 
3. Available at: http://vc.bridgew.edu/br_rev/vol33/iss1/6.

4. Holcombe, G. (2005). "Alice Munro". Contemporary Writers. London: British Arts Council. Retrieved 20 June 2007.

5. Hoy, H. (1980). "Dull, Simple, Amazing and Unfathomable: Paradox and Double Vision In Alice Munro's Fiction". Studies in Canadian Literature. University of New Brunswick. 5 (1).

6. http://www.nobelprize.org/nobel_prizes/literature/laureates/2013/pres s.pdf

7. http://www.nytimes.com/2012/11/18/books/review/dear-life-storiesby-alice-munro.html

8. https://view.officeapps.live.com/op/view.aspx?src=http://www.e-

9. teachingonline.com.ar/issue100/teachers/alice\%20munro\%20short\%2 0stories.docx

10. Munro, A. (2012). Dear Life: Stories. New York: Alfred A. Knopf.

11. MacKendrick, L.K. and Thacker, R., 1998. Some Other Reality: Alice Munro's Something I've Been Meaning to Tell You. Journal of Canadian Studies, 33(2), p.196.

12. Murphy, G., 2009. The art of Alice Munro: Memory, identity, and the aesthetic of connection. Alice Munro, pp.41-56.

13. --------. (1998). "Introduction: Alice Munro, Writing 'Home': 'Seeing This Trickle in Time,'” Essays on Canadian Writing 66 (Winter 1998): 1-20. 